\title{
PENGARUH TERAPI PURSED LIP BREATHING MENIUP BALON TERHADAP STATUS OKSIGENASI ANAK DENGAN ASMA
}

\author{
Eva Oktaviani ${ }^{1}$, Ririn Putri Damaiyanti ${ }^{2}$, M Vaizul Rahman ${ }^{3}$, Kusrini $^{4}$ \\ ${ }^{1}$ Dosen Program Studi Keperawatan Lubuklinggau Poltekkes Kemenkes Palembang, \\ ${ }^{2,3,4}$ Mahasiswa Program Studi Keperawatan Lubuklinggau Poltekkes Kemenkes Palembang \\ Alamat korespondensi: evaoktaviani@poltekkespalembang.ac.id
}

\begin{abstract}
Abstrak
Asma merupakan masalah kesehatan dunia yang serius dan dapat mempengaruhi semua kelompok usia, termasuk anak-anak. Gejala Asma pada anak dapat dikendalikan dengan pengelolaan yang dilakukan secara lengkap, tidak hanya dengan pemberian terapi farmakologis tetapi juga menggunakan terapi nonfarmakologis Terapi nonfarmakologis dapat membantu mengontrol serangan asma yaitu melalui latihan pernapasan. Latihan pernapasan dapat dilakukan dengan pursed lip breathing melalui terapi bermain meniup balon. Tujuan penelitian ini untuk mengetahui keefektifan penerapan teknik pursed lip breathing meniup balon terhadap status oksigenasi anak dengan asma. Desain penelitian adalah pre_posttest group design. Status oksigenasi berupa frekuensi pernapasan, nadi, saturasi oksigen yang diukur sebelum dan sesudah terapi pursed lip breathing. Pursed Lip Breathing dilakukan selama 15 menit dengan tiupan insipirasi 4 kali hitungan dan ekspirasi 7 kali hitungan, jeda antar siklus 2 detik. Sampel penelitian berjumlah 25 anak diambil secara purposive sampling. Tempat penelitian adalah di Desa Maur Baru dan Maur Lama Kabupaten Muara Rupit Kecamatan Musi Rawas Utara. Analisis menggunakan uji Wilcoxon pada frekuensi pernapasan, dan saturasi oksigen. Uji statistis dependent t-test digunakan pada variabel frekuensi nadi. Ada perbedaan signifikan status oksigenasi sebelum dan sesudah dilakukan pursed lip breathing dengan meniup balon. Teknik pernapasan pursed lip breathing terbukti efektif sebagai terapi nonfarmakologis yang dapat diterapkan secara rutin untuk meningkatkan status oksigenasi pada anak dengan asma, sehingga dapat mengoptimalkan fungsi mekanik paru
\end{abstract}

Kata kunci: Asma, Status Oksigenasi, Terapi Pursed Lip Breathing

\begin{abstract}
Asthma is a serious global health problem and can affect all age groups, including children. Asthma symptoms in children can be controlled with complete management, not only by administering pharmacological therapy but also using non-pharmacological therapy. Non-pharmacological therapy can help control asthma attacks, namely through breathing exercises. Breathing exercises can be pursed lip breathing through balloon blowing therapy. The purpose of this study was to determine the effectiveness of the pursed lip breathing technique by blowing a balloon on the oxygenation status of children with asthma. The research design was pre_posttest group design. Oxygenation status in the form of respiratory rate, pulse, oxygen saturation measured before and after pursed lip breathing therapy. Pursed Lip Breathing is carried out for 15 minutes with 4 breaths of inspiration and 7 times of expiration, pausing between cycles of 2 seconds. The research sample consisted of 25 children taken by purposive sampling. The research sites are in the villages of Maur Baru and Maur Lama, Muara Rupit District, Musi Rawas Utara District. The analysis used the Wilcoxon test on respiratory rate, and oxygen saturation. The dependent statistical t-test was used on the pulse frequency variable. There was a significant difference in oxygenation status before and after pursed lip breathing by blowing a balloon. Pursed lip breathing has proven to be effective as a non-pharmacological therapy that can be applied routinely to improve oxygenation status in children with asthma, so as to optimize lung mechanical function.
\end{abstract}

Keywords: Asthma, Oxygenation Status, Pursed Lip Breathing Technique 


\section{PENDAHULUAN}

Prevalensi asma di dunia akan meningkat dalam beberapa tahun mendatang. Data dari Organization (2011) menunjukkan 300 juta orang di dunia terdiagnosa asma dan diperkirakan akan meningkat menjadi 400 juta orang di tahun 2025. Berdasarkan hasil Riset RI (2018) didapatkan prevalensi asma di Indonesia sebesar 2,4\% dan merupakan peringkat ke sepuluh penyebab kesakitan dan kematian. Provinsi Sumatera Selatan sendiri menduduki peringkat ke enam penyakit Asma terbanyak di Indonesia sebesar 1,9\%. Kasus asma pada anak di Indonesia lebih tinggi sedikit dibandingkan dewasa. Prevalensi pada anak tertinggi pada usia 5-14 tahun sebesar 1,9\% dan proporsi kekambuhan dalam 12 bulan terakhir sebesar 53,9\% (Kemenkes, 2018).

Asma didefinisikan sebagai suatu kondisi ketika terjadi gangguan pada sistem pernapasan yang menyebabkan penderita mengalami mengi (wheezing), sesak napas, batuk, dan kesulitan bernafas terutama ketika malam hari atau dini hari (Boulet et al., 2019). Distress pernapasan merupakan kompensasi tubuh terhadap kekurangan oksigen karena konsentrasi oksigen yang rendah. Akibat terhambatnya suplai oksigen dalam tubuh karena kesulitan bernapas, tubuh akan menstimulasi syaraf pusat untuk meningkatkan frekuensi pernapasan. Jika upaya tersebut tidak terkompensasi maka akan terjadi gangguan status oksigenasi, dan apabila tidak ditangani dengan tepat dapat menyebabkan kematian (Ekarini, 2012; Sari, 2016).

Secara medis, penyakit asma sulit disembuhkan, namun penyakit ini dapat dikontrol sehingga tidak mengganggu aktivitas sehari-hari.
Salah satu cara mengontrol gejala yang timbul serta mengurangi keparahan gejala Asma dengan memberikan latihan pernapasan. Latihan pernapasan bertujuan untuk melatih cara bernapas yang benar, melenturkan dan memperkuat otot pernapasan, melatih ekspektorasi yang efektif, meningkatkan sirkulasi, dan menurunkan kadar IgE sebagai faktor inflamasi pada asma (Widjanegara, Tirtayasa, \& Pangkahila, 2015). Salah satu latihan pernapasan yang dapat digunakan pada anak dengan asma adalah Pursed Lip Breathing (PLB). Pursed Lips Breathing ialah latihan pernapasan yang bertujuan untuk mempermudah proses pengeluaran udara yang terjebak di dalam paru-paru dengan cara membantu melakukan penekanan pada proses ekspirasi (Qamila, Ulfah Azhar, Risnah, \& Irwan, 2019). Teknik ini merupakan salah satu upaya untuk membantu mengurangi sesak napas, mengurangi kekambuhan, dan meningkatkan fungsi kapasitas paru (Mayuni, Kamayani, \& Puspita, 2015; Royani, 2017; Kartikasari, Jenie, \& Primanda, 2019). Pursed lip breathing juga merupakan cara yang paling mudah untuk membantu pasien asma bernapas secara efektif karena peningkatan oksigenasi di paru ((Jie et al., 2019).

Latihan pursed lip ini dapat dimodifikasi dengan mengintegrasikan aktivitas bermain dengan cara meniup balon (Wong, Hockenberry-Eaton, Wilson, Winkelstein, \& Schwartz, 2010). Kombinasi dengan teknik bermain saat menerapkan intervensi PLB merupakan pilihan yang tepat karena anak-anak pada dasarnya masih sangat senang dengan permainan. Hal ini membuat anak akan semakin relaks dan melakukan teknik ini dengan perasaan riang gembira. Penelitian 
sebelumnya membuktikan bahwa bermain meniup balon (balloon therapy) dapat meningkatkan status oksigenasi anak (frekuensi pernapasan, nadi, dan saturasi oksigen) pada anak dengan gangguan saluran pernapasan (Nugroho, Dewi, \& Alam, 2018).

Teknik ini dapat meningkatkan tekanan alveolus pada setiap lobus paru, sehingga dapat meningkatkan aliran udara saat ekspirasi yang mampu mengaktifkan silia mukosa jalan napas untuk mengevakuasi sekret ke luar dari saluran napas, sehingga dapat meningkatkan status oksigenasi (Brunner, Smeltzer, \& Suddarth, 2010). Berdasarkan hasil studi pendahuluan bahwa kejadian asma pada anak di Desa Maur Lama dan Maur Baru cukup banyak dan mayoritas disebabkan karena keturunan, namun edukasi mengenai latihan mengontrol gejala asma belum pernah dilakukan. Padahal latihan pernapasan secara rutin dapat mengurangi sesak dan konsumsi, obatobatan. Selain itu, kedua desa tersebut terletak di dekat jalur perlintasan dengan paparan polusi udara yang tinggi. Polusi udara merupakan salah satu faktor risiko timbulnya asma (Dharmayanti, Hapsari, \& Azhar, 2013; Laksana et al., 2015).

Berdasarkan hal tersebut peneliti tertarik untuk mengeskplorasi sejauh mana pengaruh teknik pursed lip breathing dengan meniup balon terhadap status oksigenasi di Desa Maur Lama dan Maur Baru sebagai tempat penelitian.

\section{METODE PENELITIAN}

Penelitian ini merupakan penelitian action riset dengan one group pre_post test design. Populasi penelitian adalah anak-anak yang memiliki riwayat Asma di Desa Maur Lama dan Maur Baru Kabupaten Muara Rupit, Kecamatan Musi Rawas Utara. Pengambilan sampel menggunakan teknik purposive sampling sebanyak 25 anak. Kriteria inklusi pada penelitian ini adalah anak yang memiliki riwayat asma dengan rentang usia 3-18 tahun, anak tidak dalam keadaan demam, keluarga yang bersedia anaknya menjadi responden

Kriteria eksklusi pada penelitian ini yaitu anak pada saat pengambilan data tidak sedang mengalami serangan, kondisi anak sangat lemah sehingga tidak mampu untuk meniup balon, anak asma dengan penyakit komplikasi lainnya. Pengumpulan data dilakukan hanya satu kali pada responden dengan langsung datang ke rumah responden. Informed consent diisi oleh orang tua.

Prosedur PLB yaitu peneliti menginstruksikan responden untuk rileks, kemudian responden bernapas melalui hidung dalam 4 hitungan dengan mulut tetap tertutup, selanjutnya menginstruksikan reponden mengeluarkan napas secara perlahan dalam 7 hitungan dengan mengerucutkan mulut dan meniupkan ke balon pada model paru yang sudah didesign oleh peneliti. Peneliti menginstruksikan responden untuk melakukan PLB selama 15 menit, dengan jeda antar siklus 2 detik, kemudian mengevaluasi kondisi responden setelah perlakuan.

Pemeriksaan status oksigenasi meliputi pengukuran frekuensi pernapasan, nadi, dan saturasi oksigen. Saturasi oksigen dan nadi diukur menggunakan oksimetri kutaneous 
yang dipasang di jari tangan Status oksigenasi diukur sebelum dan sesudah latihan PLB. Penelitian ini sudah lolos uji etik dari Komite Etik Poltekkes Kemenkes Palembang.

Analisis data menggunakan uji Wilcoxon pada kelompok data frekuensi pernapasan dan saturasi oksigen. Uji dependent t-test digunakan pada kelompok data frekuensi nadi.

\section{HASIL PENELITIAN}

Berikut ini merupakan hasil penelitian mengenai karakteristik responden.

Tabel 1.

Karakteristik Responden di Desa Maur Lama dan Maur Baru Muara Rupit

\begin{tabular}{|c|c|c|c|c|}
\hline \multicolumn{5}{|c|}{ Total Sampel } \\
\hline \multicolumn{2}{|l|}{ Karakteristik } & \multicolumn{2}{|l|}{$\mathrm{n}(\%)$} & \\
\hline \multirow[t]{3}{*}{ Jenis kelamin } & Laki-laki & $12(48)$ & - & - \\
\hline & Perempuan & $13(52)$ & - & - \\
\hline & & Mean (SD) & Min-Max & $95 \% \mathrm{CI}$ \\
\hline Usia Anak (tahun) & & $7,04(3,285)$ & 3-14 & $5,68-8,040$ \\
\hline Berat badan (gram) & & $21,32(9,651)$ & $9-50$ & $17,34-25,30$ \\
\hline Tinggi Badan (cm) & & $114,36(18,572)$ & $84-155$ & $106,69-122,03$ \\
\hline
\end{tabular}

Hasil penelitian ini 52\%, dengan rerata usia anak 7,04 menunjukkan bahwa mayoritas sampel tahun. Rerata berat badan 21,32 gram berjenis kelamin perempuan sebesar dan tinggi badan $114,36 \mathrm{~cm}$.

Tabel 2.

Rerata Frekuensi Pernapasan, Nadi, Saturasi Oksigen Sebelum dan Sesudah Teknik PLB (n=25)

\begin{tabular}{lccccccc}
\hline & \multicolumn{9}{c}{ Kelompok } & \multicolumn{3}{c}{ Sesudah PLB } \\
\cline { 2 - 7 } \multicolumn{1}{c}{ Karakteristik } & \multicolumn{3}{c}{ Sebelum PLB } \\
\cline { 2 - 8 } & Mean & SD & Range & Mean & SD & Range \\
\hline Pernapasan & 22,68 & 1,725 & $20-25$ & 21,04 & 2,169 & $18-24$ & $0,001^{*}$ \\
Nadi & 90,36 & 13,143 & $64-115$ & 98,12 & 13,007 & $70-120$ & $0,001^{* *}$ \\
$\begin{array}{l}\text { Saturasi Oksigen } \\
\left(\mathrm{SpO}_{2}\right)\end{array}$ & 95,40 & 0,707 & $94-97$ & 98,16 & 0,850 & $96-100$ & $0,001^{*}$
\end{tabular}

Keterangan: *Uji Wilcoxon; ** Dependent t-test

Hasil analisis pada tabel 2 menunjukkan bahwa rerata frekuensi pernapasan sesudah dilakukan PLB lebih rendah daripada sebelum dilakukannya intervensi PLB yaitu 22,68 kali per menit menjadi 21,04 kali per menit. Rerata perubahan frekensi nadi sesudah PLB lebih tinggi dari pada sebelum intervensi yaitu 90,36 kali per menit menjadi 98,12 kali per menit.
Rerata saturasi oksigen menjadi lebih tinggi setelah dilakukannya intervensi PLB yaitu 95,40 persen meningkat menjadi 98,16 persen. Hasil uji statistik yang ditampilkan pada tabel 2 menunjukkan terdapat perbedaan yang bermakna rerata frekuensi pernapasan, nadi, dan saturasi oksigen sebelum dan setelah dilakukannya PLB ( $\mathrm{p}$ value: $0,001$; $p$ value: $0,001, p$ value $<\alpha)$. 


\section{PEMBAHASAN}

Mayoritas jenis kelamin pada sampel penelitian ini adalah perempuan sebanyak $52 \%$. Usman, Chundrayetti, dan Khairsyaf (2015) membuktikan bahwa faktor dominan yang mempengaruhi kejadian asma pada anak adalah adalah perubahan cuaca $(65,91 \%)$, debu $(63,64 \%)$, jenis kelamin $(52,80 \%)$, makanan $(43,19 \%)$. Namun, jenis kelamin tidak selalu diikuti perubahan tingkat kontrol asma (Atmoko, Hana, Evans, Masbimoro, \& Faisal, 2011). Insidensi asma pada perempuan lebih tinggi dari pada lakilaki karena perempuan lebih sering mengalami Asma yang tidak terkontrol. Menurut penelitian Andrianty dan Adiputra (2017) jenis kelamin akan mempengaruhi kapasitas vital paru karena secara anatomi sudah berbeda. Volume dan kapasitas paru pada wanita kira-kira 20-25 \% lebih kecil dari pada pria.

Rerata usia sampel pada penelitian ini adalah 7 tahun. Faktor usia juga turut mempengaruhi prevalensi penyakit asma (Laksana \& Berawi, 2015). Anak usia sekolah merupakan kelompok yang rentan terserang penyakit saluran pernapasan dan banyak yang terdiagnosis dengan asma (Setyaningrum, Rofi'i, \& Setyanti, 2016).

Berdasarkan hasil wawancara dengan orang tua anak bahwa mayoritas asma pada anak diperoleh karena keturunan. Hal ini sesuai dengan penelitian sebelumnya menyebutkan bahwa faktor risiko asma yang sangat berhubungan siginifikan pada anak-anak adalah riwayat asma pada orang tua, anak yang merokok atau pernah merokok, dan orang tua yang merokok atau pernah merokok (Dharmayanti Hapsari, \& Azhar, 2013).
Karakteristik responden lainnya yang dapat mempengaruhi status oksigenasi adalah tinggi badan. Tinggi badan seseorang mempengaruhi kapasitas paru. Semakin tinggi badan seseorang berarti parunya semakin luas sehingga kapasitas paru semakin baik (Mengkidi, 2006). Pertumbuhan anak berhubungan erat dengan peningkatan percabangan dari bronkiolus perifer dan jumlah alveoli. Berat badan digunakan untuk mengetahui indeks massa tubuh responden yang dibandingkan dengan tinggi badan. Indeks massa tubuh responden dalam penelitian ini rata-rata dalam kategori normal. Berat badan berlebih dapat menurunkan ekspansi paru dan menyebabkan kebutuhan oksigenasi berlebih untuk memenuhi kebutuhan metabolisme tubuh.

$\begin{array}{ccr}\text { Hasil } & \text { status } & \text { oksigenasi } \\ \text { pernapasan } & \text { diperoleh } & \text { adanya }\end{array}$ perubahan frekuensi pernapasan menjadi lebih rendah sebelum dan sesudah PLB karena ketika anak melakukan aktivitas bermain meniup balon yang dianalogikan dengan Pursed Lips Breathing (PLB), jumlah penyerapan atau pengambilan oksigen (inspirasi) lebih besar dibandingkan bernafas secara normal, hal tersebut terjadi agar balon dapat mengembang dan terisi udara dari hembusan udara ekspirasi. Hal ini memungkinkan oksigen yang masuk dalam jumlah besar dan dapat diserap oleh hemoglobin untuk di transportasikan ke alveoli. Inspirasi maksimal sistem pertukaran $\mathrm{O}_{2}$ dan $\mathrm{CO}_{2}$ lancar akibat dari stimulasi aplikasi bermain meniup balon. Penelitian yang serupa dilakukan oleh Sutini (2011) yang menunjukkan bahwa aktivitas bermain meniup "tiupan lidah" memberikan pengaruh positif terhadap status oksigenasi Heart Rate anak usia prasekolah dengan pneumonia. 
Latihan pernapasan pursed lip dapat membantu melenturkan dan memperkuat otot pernapasan karena penderita asma akan membutuhkan kerja keras saat ekspirasi akibat bronkiolus yang sempit, sehingga dapat meningkatkan sirkulasi (Samsuardi, 2012; Widarti, 2013).

Mengerucutkan bibir saat pernapasan membantu penderita mengosongkan paru-paru dan memperlambat laju pernapasan. Hal ini terbukti setelah dilakukan terapi PLB frekuensi pernapasan responden menjadi lebih lambat. PLB juga menyebabkan otot perut berkontraksi ketika ekspirasi, hal ini akan memaksa diafragma ke atas, dan membantu untuk mengosongkan paru-paru, akibatnya penderita asma akan bernapas lebih lambat dan lebih efisien (Suryantoro, Isworo, \& Upoyo, 2017). Pursed lip breathing dapat menurunkan sesak napas, sehingga pasien dapat toleransi terhadap aktivitas dan meningkatkan kemampuan memenuhi kebutuhan sehari hari.

Terapi bermain meniup balon merupakan permainan yang memerlukan inspirasi dalam dan ekspirasi yang memanjang untuk memfasilitasi pengeluaran karbondioksida dari tubuh yang tertahan karena obstruksi jalan napas (Zul'Irfan, Suza, \& Sitepu, 2019). Terapi bermain dengan meniup balon terbukti efektif meningkatkan fungsi paru pada anak dengan asma (Sumartini, Somantri, Suparto, Andriyani, \& Salasa, 2020).

Salah satu akibat dari serangan asma akut adalah penurunan kadar saturasi oksigen darah $\left(\mathrm{SpO}_{2}\right)$. Penurunan saturasi oksigen ini jika tidak segera ditanggulangi akan menyebabkan terjadinya hipoksia jaringan. Hasil status oksigenasi pada penelitian ini yaitu terjadi peningkatan saturasi oksigen setelah dilakukan PLB dan hasil uji statistik menunjukkan perbedaan yang signifikan. Hal ini sesuai dengan penelitian yang dilakukan Sreeletha (2016) membuktikan terapi meniup balon atau ballon therapy terbukti secara signifikan berpengaruh pada status oksigenasi saturasi oksigen serta dapat mengurangi gejala pernapasan.

Menurut Sutini (2011) semakin kuat meniup diharapkan semakin kuat pula silia bergerak untuk mendorong benda asing atau sekret keluar dari jalan nafas, sehingga pada akhirnya dapat memberikan dampak positif terhadap perubahan pernapasan, nadi, dan $\mathrm{SpO}_{2}$.

Terapi pursed lip breathing yang diintegrasikan dalam permainan meniup balon memungkinkan untuk membawa oksigen ke dalam tubuh lebih besar saat dihirup dibanding dengan bernapas normal dan hemoglobin dapat mengikat lebih banyak oksigen untuk di transportasikan ke alveoli. Aktivitas meniup balon ini juga dapat dapat menguatkan otot jantung, sehingga fungsi jantung dapat lebih optimal. Semakin banyak oksigen yang dihirup maka balon yang ditiup juga akan mengembang lebih besar.

Walaupun nilai saturasi oksigen sebelum dan sesudah di lakukan PLB masih dalam batas normal namun tampak perubahan nilai saturasi kearah yang lebih baik setelah dilakukan PLB. Hal ini menunjukkan bahwa tindakan PLB membawa pengaruh yang positif pada nilai saturasi oksigen anak. Porsi oksigen yang cukup didalam tubuh anak sangat penting karena oksigen dibutuhkan untuk mempertahankan kehidupan. Sistem pernapasan dan jantung mempunyai peranan penting dalam menyuplai kebutuhan oksigen keseluruh tubuh. 
Pada penderita asma latihan pernapasan selain ditujukan untuk memperbaiki fungsi alat pernapasan, juga bertujuan melatih penderita mengatur pernapasan jika terasa akan datang serangan, ataupun sewaktu serangan asma. Jika teknik ini dilakukan secara rutin dan benar, dapat mengoptimalkan fungsi mekanik paru.

\section{SIMPULAN DAN SARAN}

Penelitian ini membuktikan bahwa penerapan teknik pursed lip breathing melalui tiupan balon terbukti efektif dapat meningkatkan status oksigenasi pada anak dengan asma. Hal ini dapat dilihat dari adanya perbedaan yang signifikan status oksigenasi berupa rerata frekuensi pernapasan, nadi, dan saturasi oksigen sebelum dan sesudah di lakukan pursed lip breathing.

Peneliti selanjutnya diharapkan dapat meneliti dan menganalisis lebih dalam mengenai faktor-faktor yang mempengaruhi status oksigenasi pada anak dengan asma dengan jumlah sampel yang lebih banyak.

\section{DAFTAR PUSTAKA}

Andrianty, F., Adiputra, N., \& -, S. (2017). Penambahan pursed lip abdominal breathing pada latihan aerobik lebih baik dalam meningkatkan kapasitas fungsi paru penderita asma bronkial. Sport and Fitness Journal, 5(1), 42-51.

Atmoko, W., Hana, K. P., Evans, T. B., Masbimoro, W. A., \& Faisal, Y. (2011). Prevalens asma tidak terkontrol dan faktor-faktor yang berhubungan dengan tingkat kontrol asma di poliklinik asma rumah sakit persahabatan. $J$ Respir Indo, 31(2), 53-60.

Boulet, L.-P., Reddel, H. K., Bateman, E., Pedersen, S., FitzGerald, J. M.,
\& O'Byrne, P. M. (2019). The global initiative for asthma (GINA): 25 years later. European Respiratory Journal, 54(2).

Brunner, L. S., Smeltzer, S. C. O., \& Suddarth, D. S. (2010). Brunner \& Suddarth's textbook of medicalsurgical nursing; Vol. 1. Language, 27, 1114-2240p.

Dharmayanti, I., Hapsari, D., \& Azhar, K. (2013). Asma pada anak di Indonesia : Penyebab dan pencetus Asthma among children in Indonesia :causes and triggers. Jurnal Kesehatan Masyarakat Nasional, Volume 9(29), 320 326.

Ekarini, N. L. P. (2012). Analisis faktor-faktor pemicu dominan terjadinya serangan asma pada pasien asma. Tesis tidak dipublikasikan. Depok: Fakultas Ilmu Keperawatan Program Magister Ilmu Keperawatan.

Jie, L. W., Govind, S., Singh, K., Wah, Y. C., Vamsi, G. S., Chinnavan, E., ... Kaur, M. (2019). A comparative study between breathing control and pursed lip breathing among bronchial asthma patients. International Journal of Advanced Science and Technology, 28(16), 1643-1648.

Kartikasari, D., Jenie, I. M., \& Primanda, Y. (2019). Latihan pernapasan diafragma meningkatkan arus puncak ekspirasi (ape) dan menurunkan frekuensi kekambuhan pasien asma. Jurnal Keperawatan Indonesia, 22(1), 53-64. http://doi.org/10.7454/jki.v22i1.6 91

Kemenkes. (2018). Salam Sehat! Semoga fakta yang disajikan dalam buku ini , bermanfaat untuk perbaikan perencanaan pembangunan kesehatan. Laporan 
Riskesdas Nasional 2018, 120.

Laksana, M. A., Berawi, K. N., Kedokteran, F., Lampung, U., Fisiologi, B., Kedokteran, F., \& Lampung, U. (2015). Faktor faktor yang berpengaruh pada timbulnya kejadian sesak napas penderita asma bronkial factors factors influencing the incidence of genesis shortness of breath bronchial asthma sufferers. Majority, 4. Retrieved from http://juke.kedokteran.unila.ac.id/ index.php/majority/article/view/1 409/1253

Mayuni, A.I.D., Kamayani, M.O.A., \& Puspita, L.M. (2015). Pengaruh diaphragmatic breathing exercise terhadap kapasitas vital paru pada pasien asma di wilayah kerja puskesmas III Denpasar Utara COPING Ners Journal, 3(2), 3136.

Mengkidi, D. (2006). Gangguan fungsi paru dan faktor-faktor yang mempengaruhinya pada karyawan pt. Semen tonasa pangkep sulawesi selatan. Program Pascasarjana Universitas Diponegoro.

Nugroho, A., Dewi, I., \& Alam, A. (2018). Pengaruh bermain pursed lips breathing terhadap status oksigenasi anak usia 3-5 tahun dengan pneumonia di rumah sakit tk. Ii pelamonia. Bimiki, 6(2), 3945 .

Organization, W. H. (2011). Atlas of headache disorders and resources in the world 2011. Geneva: World Health Organisation.

Qamila, B., Ulfah Azhar, M., Risnah, R., \& Irwan, M. (2019). Efektivitas teknik pursed lipsbreathing pada pasien penyakit paru obstruksi kronik (ppok): Study systematic review. Jurnal Kesehatan, 12(2), 137. http://doi.org/10.24252/kesehatan .v12i2.10180

RI, K. (2018). Hasil utama riskesdas 2018. Jakarta: Kemenkes RI.

Royani, E., Amerika, D., \& Balon, T. M. (2017). Pengaruh terapi aktivitas bermain meniup balon terhadap perubahan fungsi paru pada anak dengan asma di rumah sakit islam siti khodijah palembang. Maker Medika, 5, 7987.

Samsuardi, S. (2012). Manfaat latihan penguatan otot-otot pernapasan terhadap peningkatan kapasitas vital paru pada penderita asma. Disertasi tidak dipublikasikan. Universitas Muhammadiyah Surakarta.

Sari, S. N. (2016). Penerapan asuhan keperawatan gawat darurat pada pasien dengan asma bronchial di ruang rawat inap paru rsup dr. $\mathrm{M}$. Djamil padang tahun 2016.

Setyaningrum, R., Rofi'i, A., \& setyanti, a. (2016). tingkat pengetahuan dan sikap tentang cuci tangan pakai sabun (ctps) pada siswa SDN Batuah I dan batuah III Pagatan. Jurnal Berkala Kesehatan, 1(1), 43-47. http://doi.org/10.20527/jbk.v1i1.6 60

Sreeletha, A. (2016). Effect of balloon therapy v/s spirometry in promotion of respiratory function in children with respiratory infection. International Journal of Nursing Research (IJNR). 2(1), 123-132.

Sumartini, S., Somantri, B., Suparto, T. A., Andriyani, S., \& Salasa, S. (2020). The effect of playing blowing balloon therapy to changes in lung function in preschool children (3-5 years old) with asthma, 21(Icsshpe 2019), 238-241. 
http://doi.org/10.2991/ahsr.k.200 214.063

Suryantoro, E., Isworo, A., \& Upoyo, A. S. (2017). Perbedaan efektivitas pursed lips breathing dengan six minutes walk test terhadap forced expiratory. Jurnal Keperawatan Padjadjaran, 5(2), 99-112.

http://doi.org/10.24198/jkp.v5i2.4 48

Sutini, T. (2011). Pengaruh aktivitas bermain meniup tiupan lidah terhadap status oksigenasi pada anak usia prasekolah dengan pneumonia di Rumah sakit Islam Jakarta. Tesis FIK-UI.

Usman, I., Chundrayetti, E., \& Khairsyaf, O. (2015). Faktor risiko dan faktor pencetus yang mempengaruhi kejadian asma pada anak di rsup dr. M. Djamil padang. Jurnal Kesehatan Andalas, 4(2), 392-397. http://doi.org/10.25077/jka.v4i2.2 60

Widarti, R. (2013). Pengaruh Diafragmatic Breathing Exercise terhadap Peningkatan Kualitas Hidup Penderita Asma.

Widjanegara, I. G., Tirtayasa, K., \& Pangkahila, A. (2015). Senam asma mengurangi kekambuhan dan meningkatkan saturasi oksigen pada penderita asma di poliklinik paru rumah sakit umum daerah wangaya denpasar. Sport and Fitness Journal, 3(2), 1.

Wong, D. L., Hockenberry-Eaton, M., Wilson, D., Winkelstein, M. L., \& Schwartz, P. (2010). Wong's essentials of pediatric nursing, ed.
6, St. Louis, 2001. Copyrighted by Mosby, Inc, 1301.

Zul'Irfan, M., Suza, D. E., \& Sitepu, N. F. (2019). Perbandingan latihan napas buteyko dan latihan blowing balloons terhadap perubahan arus puncak ekspirasi pada pasien asma. Jurnal Perawat Indonesia, 3(2), 93-100. 